\section{An investigation into fracture toughness and mechanisms in anisotropic rocks using the Acoustic Emission method}

The Mining-Geology-Petroleum Engineering Bulletin UDC: $622.2: 624^{-1}$

DOI: 10.17794/rgn.2020.2.2

Original scientific paper

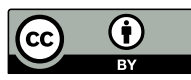

\author{
Hadi Zadsar', Masoud Cheraghi Seifabad ${ }^{2}$, Morteza Ahmadi ${ }^{3}$ \\ ${ }^{1}$ PhD. Student, Department of Mining Engineering, Isfahan University of Technology, Isfahan, 8415683111, Iran. \\ ${ }^{2}$ Department of Mining Engineering, Isfahan University of Technology, Isfahan, 8415683111, Iran. \\ ${ }^{3}$ Rock Mechanics Gr., Department of Mining Engineering, Faculty of Engineering, Tarbiat Modares University, 1411713116 , Tehran, Iran.
}

\begin{abstract}
Anisotropy in rock is among the important parameters that should be considered in studying fracture toughness and fracture mechanisms. Acoustic emission is one of the methods applied to investigate fracture mechanics and how microcracks grow in rock samples. This method can help to identify different parts of stress versus strain curves. Using this method, the current research aims to study the effect of anisotropy angles on fracture toughness and fracture mechanisms of rock samples. To study the designated parameters, the Cracked Chevron Notched Brazilian Disc (CCNBD) method was selected. Blocks of slate, as an anisotropic rock, were prepared from the Sanandaj-Sirjan zone in Iran. The sample sizes were $54 \mathrm{~mm}$ and $74 \mathrm{~mm}$ in diameter and $24 \mathrm{~mm}$ and $37 \mathrm{~mm}$ in thickness, respectively, and their anisotropy angles were $0^{\circ}, 15^{\circ}, 30^{\circ}, 45^{\circ}, 60^{\circ}, 75^{\circ}$, and $90^{\circ}$. The tests were carried out in accordance with the method suggested by the International Society for Rock Mechanics (ISRM). Two acoustic sensors were mounted on the specimens to log acoustic waves and determine the acoustic parameters (rise angle and average frequency) for fracture mechanism analysis. About 10 tests were carried out for each angle of anisotropy. Based on the obtained results, it was inferred that anisotropy affects the strength and fracture toughness of rock samples. By increasing the anisotropy angle from $\mathrm{o}^{\circ}$ to $30^{\circ}$, the strength and fracture toughness decreased. Exceeding this range of angle, with an increase in the anisotropy angle, the strength and fracture toughness increased as well.
\end{abstract}

Keywords:

Acoustic emission, anisotropic rock failure, fracture toughness, fracture mechanism

\section{Introduction}

Investigating the behavior of rock under loading and determining its mechanical properties is a major concern in the design of a rock structure. Therefore, rock strength and rock deformation should be carefully determined for designing rock structures. Further, anisotropy is a crucial factor to be considered in determining the properties (Xing et al., 2018, Gao et al., 2010, Togashi et al., 2018). The fracture of anisotropic rocks and the growth of cracks in rocks such as slate have been investigated by different researchers (Debecker and Vervoort, 2013, Clark and Fisher, 1995).

Fracture toughness or the critical stress intensity factor are considered as important parameters of the intrinsic property of rocks in studying fracture mechanics (Eberhardt et al., 1998, Akhyani et al., 2018, Kirby and McCormick, 2017). To date, different tests have been proposed to determine the fracture toughness in both static and dynamic loading conditions for three

Corresponding author: Masoud Cheraghi Seifabad cheraghi@cc.iut.ac.ir modes. Among the modes to determine fracture toughness in rocks is mode I (Fowell et al., 1991, Atkinson and Craster, 1995, Su et al., 2019, Meng et al., 2018). Studying the mechanism, the process of cracking, and the growth of micro-cracks provides useful information for stability analysis and determining the damage level to materials. In this regard, some studies suggest measuring fracture toughness of rock samples with the Cracked Chevron Notched Brazilian Disc (CCNBD) test (Fowell and Xu, 1993).

The acoustic emission method could be used in rock fracture mechanics to investigate how micro-cracks grow in samples. This phenomenon is defined as the emission of elastic waves due to the release of energy in the sample under stress during the formation of microcracks. In this method, the changes in the stress mechanism within the specimens are measured under different loading and environmental conditions. In this way, the obtained results can be used to create an assessment and instant alert system for a variety of concrete structures. An increase in the hit rate indicates an increase in the level of damage (Grosse and Ohtsu, 2008, Nair and Cai, 2010). This method has a high potential in analyz- 


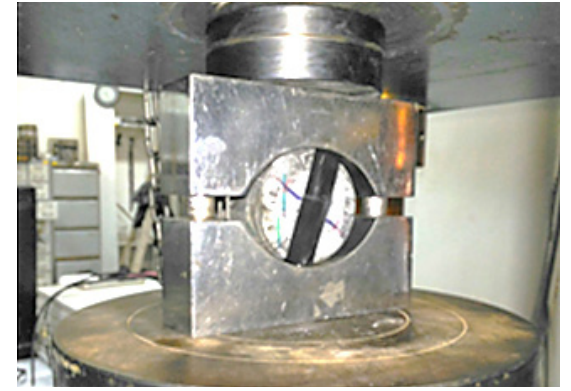

Figure 1: Brazilian disc specimen loading.

ing the behaviors of cracks from the early formation stages of micro-cracks to the final formation stages of large cracks. There are various sources for these kinds of acoustic waves in materials such as structure deformation that is in the form of elastic deformation, the appearance of micro-cracks, and the development of large cracks (Sause and Hamstad, 2018, Aggelis et al., 2015). After logging different acoustic data, variations of different parameters of acoustic emissions such as hit, amplitude, rise angle (RA), and average frequency (AF) are used for fracture analysis.

Two types of cracks have been proposed to obtain fracture toughness in rock specimens. These two are:

a - through-thickness cracking and

$\mathrm{b}-$ Chevron notch cracking.

The chevron notch crack is suitable to obtain toughness of mode I. ISRM has proposed three methods for preparing specimens with a chevron notch; i.e., $\mathrm{SR}^{1}$, $\mathrm{CB}^{2}$, and CCNBD (Aminzadeh et al., 2019).

In this research, fracture toughness and mechanisms of anisotropic rock samples are studied. The goal was to determine the fracture toughness of anisotropic rock samples at different angles of anisotropy and analyze fracture mechanisms using the acoustic emission method.

\section{Experiments}

Before starting experiments, the type and procedure of the tests for anisotropic rock samples were studied. Then a schedule was designed for these tests. Specimens required for the tests, the specifications, and the location of blocks were identified. Selected blocks were sent to the laboratory for sample preparation.

\subsection{Specimen}

Slate as an anisotropic rock was chosen for the purpose of this research. Rock blocks were collected from shale units of the Sanandaj-Sirjan zone in the Kurdistan province, west of Sanandaj city, Iran. Shale layers have been deformed into Slates and Phillies due to the metamorphism phenomenon. After collecting and selecting

\footnotetext{
${ }^{1}$ Short Rod

${ }^{2}$ Chevron Bend
}

the blocks, the specimens were prepared in the form of a Brazilian Disc. Samples with two different diameters were used to investigate the effect of diameter on the results. The sizes were $54 \mathrm{~mm}$ and $74 \mathrm{~mm}$ in diameter and $24 \mathrm{~mm}$ and $37 \mathrm{~mm}$ in thickness, respectively.

\subsection{Testing Method}

To find and select the best and simplest test for determining fracture toughness, three tests of SR, CB and CCNBD were compared in terms of:

1 - Length and diameter of specimen, in brittle rocks; if these are too large, they will cause some problems such as damaging the prepared samples (Briševac et al., 2015),

2 - The load applied to break the specimen; the simplest method of loading is compression,

3 - Procedure and equipment for testing; and

4 - Accuracy in fracture toughness determination.

Based on these four conditions, the CCNBD test was chosen as a suitable test for the purpose of this study. The most important features of this test are its convenient specimen preparation, its simplicity of testing, and the minimum requirements of specimens. Moreover, the load for the failure of a specimen is enough big in this test and so it is possible to determine fracture toughness.

In this research, the CCNBD test was applied to determine the fracture toughness of anisotropy samples according to the ISRM suggested method. To study fracture mechanisms, during the tests, acoustic waves were logged by the acoustic estimation (AE) method. Disc specimens with diameters of 54 $\mathrm{mm}$ and $74 \mathrm{~mm}$ and chevron notches were used to determine tensile strength and fracture toughness. The anisotropy angle of these specimens varied from $0^{\circ}$ to $90^{\circ}$ with a variation of $15^{\circ}$. For each angle of anisotropy, 10 tests were carried out. In Figure 1, the test set-up is presented.

\subsection{Acoustic data acquisition}

The fracture mechanism was investigated using the $\mathrm{AE}$ method. The device mode I used to record the acoustic waves created inside the specimens is the AMSY-5, manufactured by Vallen System GmbH. This device is used to $\log$ the acoustic waves. Acoustic sensors were mounted on the specimen as shown in Figure 2.

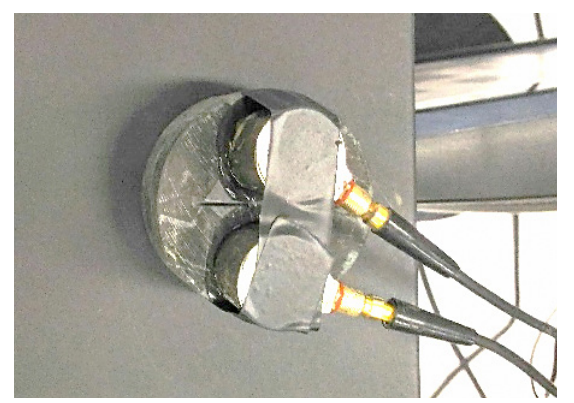

Figure 2: Acoustic sensors mounted on the sample on both sides of the Chevron notch. 
Table 1: Acoustic parameters for different anisotropy angles.

\begin{tabular}{|l|c|c|c|}
\hline $\begin{array}{l}\text { Anisotropy } \\
\text { angle } \\
\text { (degree) }\end{array}$ & $\begin{array}{c}\text { Max. force } \\
\text { applied (kN) }\end{array}$ & $\begin{array}{c}\text { Average } \\
\text { frequency } \\
\text { (kHz) }\end{array}$ & $\begin{array}{c}\text { Rise Angle } \\
\text { (ms/V) }\end{array}$ \\
\hline 0 & 13 & 40.5 & 1 \\
\hline 15 & 6 & 20.6 & 39 \\
\hline 30 & 7 & 3.4 & 42.6 \\
\hline 45 & 8 & 28.7 & 14.6 \\
\hline 60 & 9 & 23 & 20.9 \\
\hline 75 & 10 & 15.5 & 26.7 \\
\hline 90 & 11 & 9.5 & 33.5 \\
\hline
\end{tabular}

According to the acoustic analysis, the stress-strain curve consists of six parts (Moradian et al. 2015) of original crack closure, linear elastic deformation, microcrack initiation, micro-crack growth (stable crack), large crack growth (unsafe crack), and failure.

By applying stress, in the early stage of crack closures, the occurrence rate of events (single count for hits detected by two sensors in a predetermined period of time, which were distributed in the area between the loading plate and the specimens (Agioutantis et al., 2016)) is high. The rate decreases with increasing stress during plastic deformation. By continuing with the stress, micro-cracks appear and the rate decreases. Then, with further increasing stress, the rate increases because of the initiation of a macro-crack. Finally, at the failure step, a significant reduction is recorded in the event rate.

RA parameter (i.e., the ratio of rise time to wave amplitude) and AF parameter (i.e., the ratio of counts to time duration) can be used to identify the mechanism of micro-cracks in the specimens. These parameters for the tests carried out in this study are presented in Table 1. The mechanism for the creation of micro-cracks is accounted by a tensile mode when the RA is low and the $\mathrm{AF}$ is high. In addition, when the RA is high and the $\mathrm{AF}$ is low, shear mode is the mechanism responsible for the creation of micro-cracks. If these two parameters are equal, then the mechanism for creating micro-cracks is a mixed-mode. In specimens with a smaller diameter, as the acoustic sensors were very close and could affect each other, the acoustic sensors were installed only on the larger diameter specimens.

\section{Test results}

\subsection{Fracture Toughness}

The fracture toughness was determined according to Equation 1. In this equation, $Y$ is calculated from Equation 2.

$$
K_{\mathrm{Ic}}=\frac{\mathrm{P}_{\max }}{\sqrt{\mathrm{RB}}} Y_{\min }^{*}
$$

where:

$$
\begin{aligned}
& \mathrm{P}_{\text {max }} \text { - fracture load }(\mathrm{kN}), \\
& \mathrm{B} \text { - sample thickness }(\mathrm{mm}), \\
& \mathrm{R} \text { - radius }(\mathrm{mm}) .
\end{aligned}
$$

$$
Y_{\min }^{*}=u e^{v \alpha_{1}}
$$

$\alpha_{1}-$ the final length of chevron notch

$u$ and $v$ are values dependent on $\alpha_{0}$ and $\alpha_{\mathrm{B}}$, obtained from the table presented in the proposed method at the ISRM suggested method (Fowell et al., 1995).

The results of CCNBD tests are presented in Table 2. Fracture toughness values at different angles of anisotropy were compared in specimens with two different sizes, namely, $54 \mathrm{~mm}$ in diameter with $24 \mathrm{~mm}$ thickness and $74 \mathrm{~mm}$ in diameter with $37 \mathrm{~mm}$ thickness.

In Figure 3, fracture toughness is presented versus the anisotropy angle for various sample diameters. As can be seen, the larger the diameter of the sample, the more resistant it would be to failure. The maximum load applied at failure time was considered in calculations. The fracture patterns of the specimens are shown in Figure 4-a. The formation of wing cracks in some samples is illustrated in Figure 4-b. The development and continuity of wing cracks are the main cause of failure. Crack

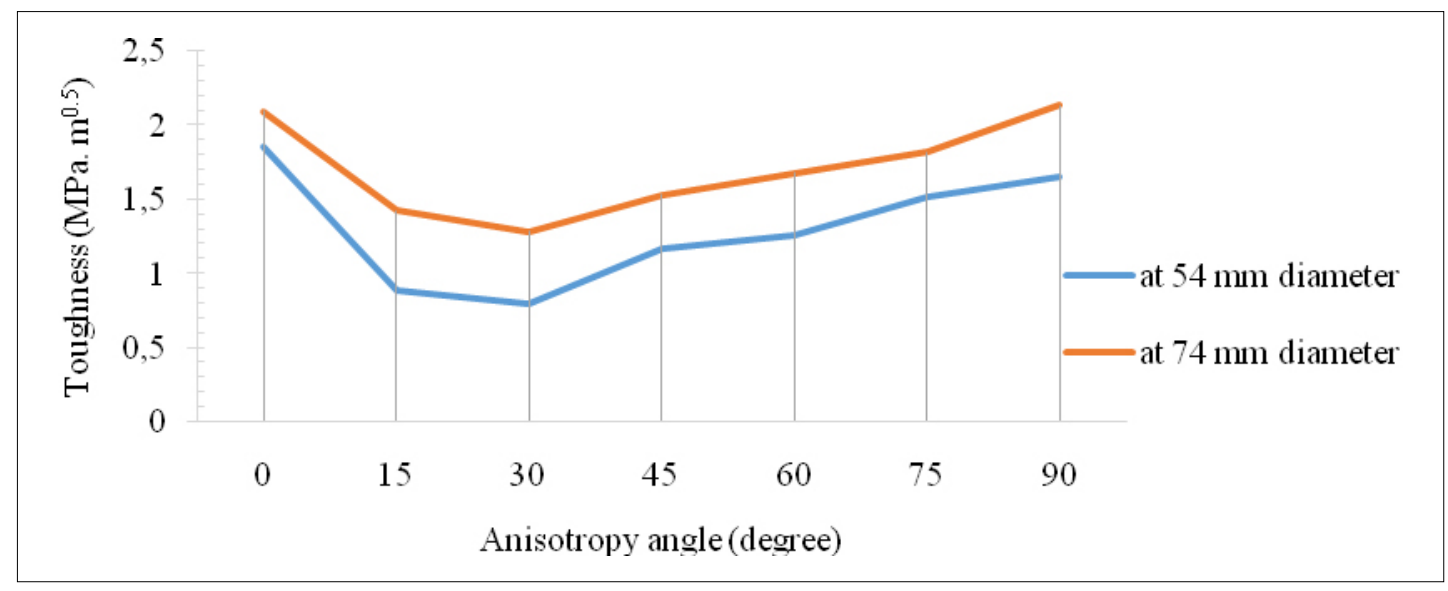

Figure 3: Fracture toughness vs. anisotropy angle for different sample diameters. 


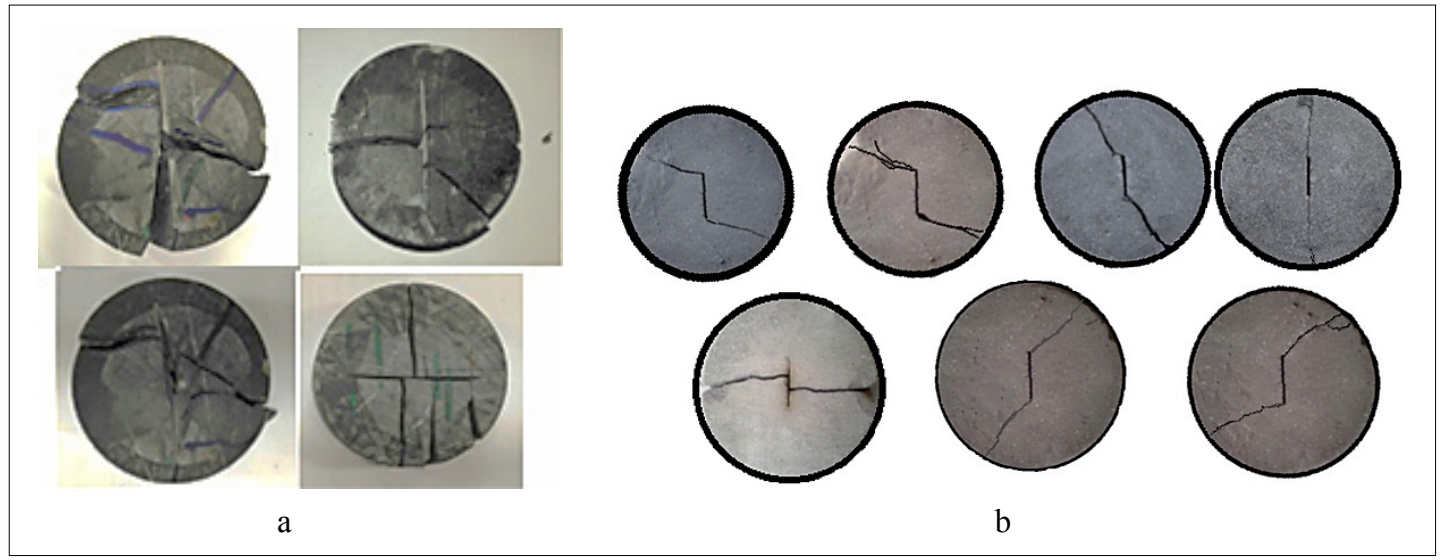

Figure 4: a) Failure pattern of some samples, b) Wing crack creation in some samples.

Table 2: Fracture toughness for different angles of anisotropy.

\begin{tabular}{|c|c|c|c|c|c|c|}
\hline Angle(degree) & Load ap & ed $(\mathrm{kN})$ & Toughnes & $\left.\mathrm{MPa} \cdot \mathrm{m}^{0.5}\right)$ & Specimen s & fter failure \\
\hline$\alpha$ & $\begin{array}{c}P \\
(D=54 \mathrm{~mm})\end{array}$ & $\begin{array}{c}P \\
(D=74 \mathrm{~mm})\end{array}$ & $\begin{array}{c}K_{I} \\
(D=54 \mathrm{~mm})\end{array}$ & $\begin{array}{c}K_{I} \\
(D=74 \mathrm{~mm})\end{array}$ & $D=54 \mathrm{~mm}$ & $D=74 \mathrm{~mm}$ \\
\hline 0 & 11 & 19.1 & 1.86 & 2.096 & & \\
\hline 15 & 5.2 & 12.5 & 0.895 & 1.425 & & \\
\hline 30 & 4.6 & 11.5 & 0.801 & 1.283 & & \\
\hline 45 & 6.8 & 13.9 & 1.174 & 1.534 & & \\
\hline 60 & 7.2 & 15.8 & 1.265 & 1.680 & & \\
\hline 75 & 8.8 & 17.2 & 1.526 & 1.819 & & \\
\hline 90 & 9.6 & 18.9 & 1.655 & 2.138 & & \\
\hline
\end{tabular}


growth and failure development are propagated from the crack tip for specimens with discontinuity angles below $60^{\circ}$. At these angles, crack propagation from the hypothetical crack tip (Chevron Notch) breaks the specimens, while for angles greater than $75^{\circ}$, tensile failure occurs.

Therefore, when the angle exceeds $75^{\circ}$, the crack has no effect on the crack growth direction and specimen failure because the stress intensity decreases in the cracked areas. The tensile failure mode occurred in samples with angles of $0^{\circ}, 75^{\circ}$, and $90^{\circ}$.

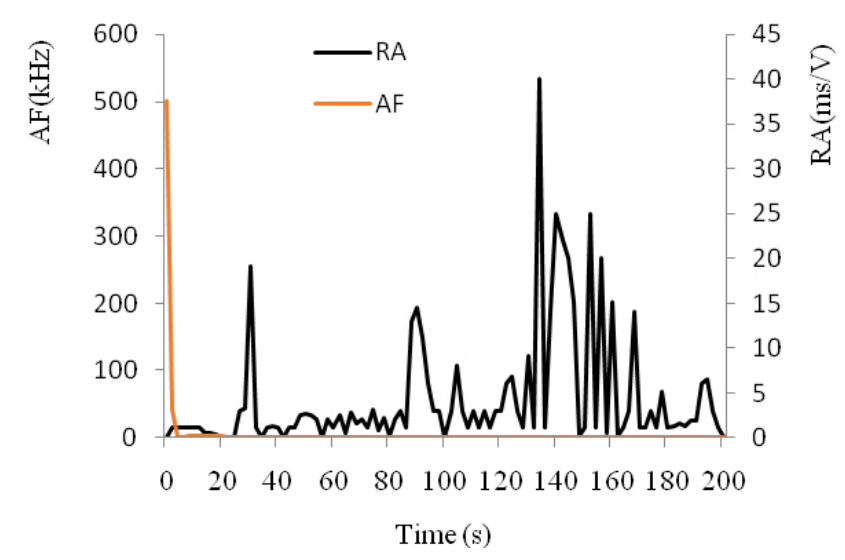

Figure 5: Changes in RA and AF with time.

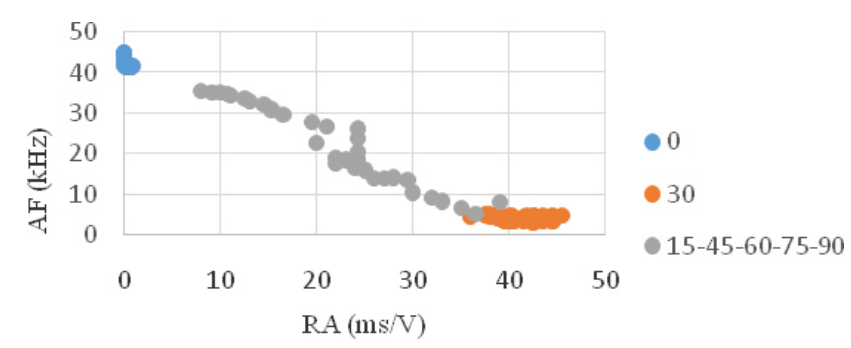

Figure 6: RA with AF for different anisotropy angles at the beginning of loading.

\subsection{Acoustic analysis}

Data regarding crack growth initiation and crack propagation could be of great use during the acoustic analysis. There are several methods to recognize crack initiation; e.g., volumetric, lateral, and axial strain methods. Considering the lower accuracy of these methods, the acoustic emission method is widely used to identify the fracture behavior of rocks and estimate the cracking process (Nair and Cai, 2010, Green, 2018). This method is a suitable approach for analyzing fracture mechanics. Acoustic emission has different analyses depending on the applied parameters. The failure mechanism and micro-crack initiation were investigated.

Figure 5 illustrates changes in the RA parameter (rise time to wave amplitude) and AF parameter (ratio of counts to duration) with time. As shown, the AF value is high at the beginning of the graph while RA is low. With the passage of time, AF decreases and RA increases. So, it is concluded that initially the tensile micro-cracks in the specimen are created. Later, the amount of tensile micro-cracks decreases while the amount of shear micro-cracks increases.

RA with AF for different anisotropy angles is presented in Figure 6. The figure shows that shear mode occurs when the anisotropy angle is $30^{\circ}$ and tensile mode occurs when the anisotropy angle is $0^{\circ}$. In other angles, the mode is a mixed mode. Therefore, the fracture mechanism is different for different anisotropy angles. Figure 7 presents variations of RA with AF for different anisotropy angles when a $100 \%$ load is applied. In the specimens tested (Fig. 6 and Fig. 7), at failure time, the high values of RA (above 35) correspond to an anisotropy angle of $30^{\circ}$. Further, at failure time, high values of $\mathrm{AF}$ (above 400) correspond to an anisotropy angle of $0^{\circ}$. If the ratio of AF to RA exceeds 7.37, the shear mode will occur. For ratios less than 0.15 , tensile mode will occur and for values in-between, the mode is mixed mode.

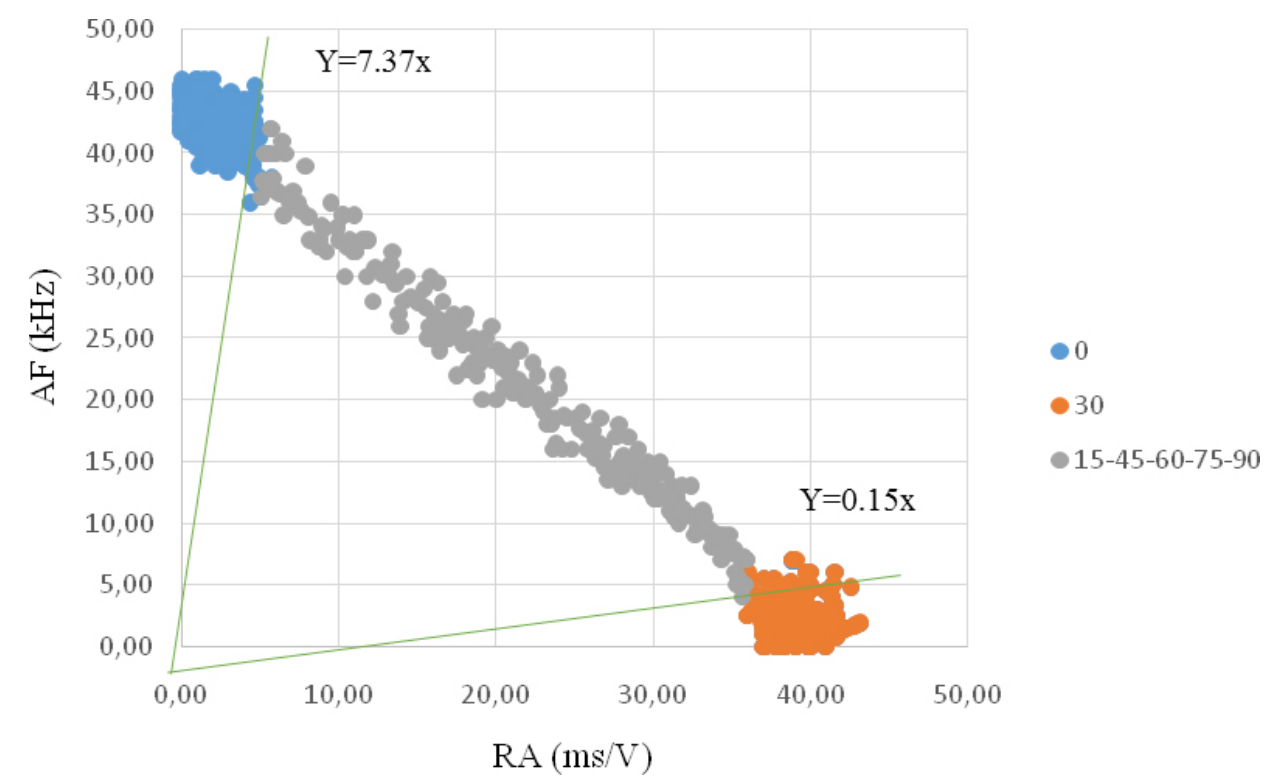

Figure 7: RA with AF for different anisotropy angles when a 100\% load is applied. 
In the anisotropic samples, the distance between the sensors and the source of the acoustic wave was low. Reflex acoustic waves may be generated by the incidence of waves by discontinuity surface (schistosity). Therefore, to identify the failure mechanism with an acoustic emission method, it is necessary to omit these reflex acoustic waves.

\section{Conclusion}

In this study, fracture toughness and fracture mechanisms of slate samples as anisotropic rocks were studied at different anisotropy angles. The acoustic emission method was used to understand the crack propagation and crack growth initiation. The Cracked Chevron Notched Brazilian Disc (CCNBD) method was used for testing the prepared samples according to the ISRM method. Anisotropy affected the strength and fracture toughness of the slate. By increasing the anisotropy angle from $0^{\circ}$ to $30^{\circ}$, the strength and fracture toughness decreased; however, with an increase in the anisotropy angle, the strength and fracture toughness increased as well. Shear mode occurred when the anisotropy angle was $30^{\circ}$, and the tensile mode occurred when the anisotropy angle was zero. In other angles, the mode was a mixed mode. Decreasing the average frequency (AF) and increasing the rise angle (RA) during the loading of anisotropic specimens indicated that the tensile microcracks were initially created, followed by the formation of shear micro-cracks. At the failure time, high values of RA corresponded to the anisotropy angle of $30^{\circ}$ and high values of $\mathrm{AF}$ corresponded to the anisotropy angle of $0^{\circ}$. The formation of micro-cracks and ultimate failure can be studied by analyzing the amount of applied stress and hit rate data. This study showed that acoustic parameters such as hit count increase momentarily and cumulatively correspond to stress levels during the formation of micro-cracks. In this regard, hit count could be considered as an index for the failure process. Investigating the formation of micro-cracks and the type and path of the failure on various types of rocks requires further research in the future. Also, to avoid limitations of experiments, more research should be carried out to omit reflex acoustic waves.

\section{References}

Aggelis, D., Mpalaskas, A. and Matikas, T. (2015): Acoustic Emission (AE) and Related Non-destructive Evaluation (NDE) Techniques in the Fracture Mechanics of Concrete. Ohtsu, M. (ed.): Acoustic monitoring for the evaluation of concrete structures and materials. Woodhead Publ., 269-286, $318 \mathrm{p}$.

Agioutantis, Z., Kaklis, K., Mavrigiannakis, S., Verigakis, M., Vallianatos, F. and Saltas, V. (2016): Potential of acoustic emissions from three-point bending tests as rock failure precursors. International journal of mining science and technology, 26, 155-160.
Akhyani, M., Sereshki, F. and Mikaeil, R. (2018): An Investigation of the Effect of Toughness and Brittleness Indexes on Ampere Consumption and Wear Rate of a Circular Diamond Saw. Rudarsko-geološko-naftni zbornik (The Mining-Geological-Petroleum Engineering Bulletin), 33, 85-92.

Aminzadeh, A., Fahimifar, A. and Nejati, M. (2019): On Brazilian disk test for mixed-mode I/II fracture toughness experiments of anisotropic rocks. Theoretical and Applied Fracture Mechanics, 102, 222-238.

Atkinson, C. and Craster, R. (1995): Theoretical aspects of fracture mechanics. Progress in Aerospace Sciences, 31, 1-83.

Briševac, Z., Kujundžić, T. and Čajić, S. (2015): Current cognition of rock tensile strength testing by Brazilian test. Rudarsko-geološko-naftni zbornik (The Mining-GeologicalPetroleum Engineering Bulletin), 30, 101-114.

Clark, M. B. and Fisher, D. M. (1995): Strain partitioning and crack-seal growth of chlorite-muscovite aggregates during progressive noncoaxial strain: an example from the slate belt of Taiwan. Journal of Structural Geology, 17, 461-474.

Debecker, B. and Vervoort, A. (2013): Two-dimensional discrete element simulations of the fracture behavior of slate. International Journal of Rock Mechanics and Mining Sciences, 61, 161-170.

Eberhardt, E., Stead, D., Stimpson, B. and Read, R. (1998): Identifying crack initiation and propagation thresholds in brittle rock. Canadian Geotechnical Journal, 35, 222-233.

Fowell, R., Hudson, J., Xu, C. and Zhao, X. (1995): Suggested method for determining mode I fracture toughness using cracked chevron notched Brazilian disc (CCNBD) specimens. International Journal of Rock Mechanics and Mining Sciences and Geomechanics Abstracts, 32, 322.

Fowell, R. and Xu, C. (1993): The cracked chevron notched Brazilian disc test-geometrical considerations for practical rock fracture toughness measurement. International journal of rock mechanics and mining sciences \& geomechanics abstracts, 30, 821-824.

Fowell, R., Xu, C. and Chen, J. (1991): The CCNBD test for cutting performance prediction. International Society for Rock Mechanics and Rock Engineering, 29,337.

Gao, Z., Zhao, J. and Yao, Y. (2010): A generalized anisotropic failure criterion for geomaterials. International Journal of Solids and Structures, 47, 3166-3185.

Green, D. J. (2018): Transformation Toughening of Ceramics. CRC press, Taylor \& Francis Group, Florida, 227 p.

Grosse, C. U. and Ohtsu, M. (2008): Acoustic emission testing. Springer, Le-tex, Leipzig.149-180, 403 p.

Kirby, S. H. and McCormick, J. W. (2017): Inelastic properties of rocks and minerals: strength and rheology. CRC press, Taylor \& Francis Group, London, $354 \mathrm{p}$.

Meng, T., Zhang, D., Hu, Y., Jianlin, X., Sufang, S. and Xiaoming, L. (2018): Study of the deformation characteristics and fracture criterion of the mixed mode fracture toughness of gypsum interlayers from Yunying salt cavern under a confining pressure. Journal of Natural Gas Science and Engineering, 58, $1-14$.

Moradian, Z., Einstein, H. H. and Ballivy, G. (2016): Detection of cracking levels in brittle rocks by parametric analysis of the acoustic emission signals. Rock Mechanics and Rock Engineering, 49, 785-800. 
Nair, A. and Cai, C. (2010): Acoustic emission monitoring of bridges: Review and case studies. Engineering structures, 32, 1704-1714.

Sause, M. and Hamstad, M. (2018): Comprehensive Composite Materials II. Beaumont, P.W.R. and Zweben, C.H. (eds): Acoustic Emission Analysis. - Elsevier Publ., 291-326, 4288p.

Su, X., Chen, P. and Ma, T. (2019): Evaluation of shale fracture toughness based on micrometer indentation test. Petroleum, 5 , $52-57$.
Togashi, Y., Kikumoto, M. and Tani, K. (2018): Determining anisotropic elastic parameters of transversely isotropic rocks through single torsional shear test and theoretical analysis. Journal of Petroleum Science and Engineering, 169, 184-199.

URL: https://www.vallen.de/downloads/, Vallen System GmbH

Xing, Y., Kulatilake, P. and Sandbak, L. (2018): Effect of rock mass and discontinuity mechanical properties and delayed rock supporting on tunnel stability in an underground mine. Engineering Geology, 238, 62-75.

\section{SAŽETAK}

\section{Istraživanje čvrstoće i mehanizma nastanka fraktura u anizotropnim stijenama metodom odašiljanja zvuka}

Anizotropija u stijenama jedan je od najvažnijih parametara u istraživanju fraktura. Ispitivanje zvučnim valovima metoda je koja se upotrebljava za proučavanje nastanka i rasta mikrofraktura. Tako se mogu prepoznati vrste stresa i naprezanja. U ovome radu istražen je utjecaj kuta anizotropije na čvrstoću i postanak fraktura uporabom metode Cracked Chevron Notched Brazilian Disc (CCNBD). Ispitani su uzorci slejta kao tipske anizotropne stijene, uzeti u zoni SanandajSirjan u Iranu. Veličina uzoraka bila je promjera 54 i $74 \mathrm{~mm}$ te debljine 24 i $37 \mathrm{~mm}$. Za ispitivanje su odabrani anizotropni kutovi $0^{\circ}, 15^{\circ}, 30^{\circ}, 45^{\circ}, 60^{\circ}, 75^{\circ}$ i $90^{\circ}$. Testovi su načinjeni s preporukama Međunarodnoga društva za mehaniku stijena (International Society for Rock Mechanics - ISRM). Zvučni prijamnici postavljeni su na uzorke te je obavljena zvučna karotaža (povećanjem kuta snimanja i prosječne frekvencije). Za svaki kut promatranja anizotropije načinjeno je 10 testiranja. Opaženo je kako se učinci anizotropije odražavaju u čvrstoći fraktura. Povećanjem kuta s o na $30^{\circ}$ čvrstoća se smanjila. Daljnje povećanje vrijednosti toga kuta dovelo je do ponovnoga rasta čvrstoće.

\section{Ključne riječi:}

zvučna karotaža, lom anizotropne stijene, čvrstoća fraktura, nastanak fraktura

\section{Authors contribution}

Hadi Zadsar (PhD Candidate): participated in all work stages such as providing samples, running experimental tests and data analyses. Masoud Cheraghi Seifabad (Associate Professor): shared contributions throughout the whole process and data analyses. Morteza Ahmadi (Full Professor): helped with the initial idea, and shared contributions in all phases of research. 